\title{
Da representação à representatividade trans: a historiografia do travestismo no teatro ludovicense ${ }^{1}$ \\ From representation to trans representativeness: the historiography of transvestism in the ludovicente theater \\ Fernanda Areias Oliveira ${ }^{2}$ \\ Fernando Augusto do Nascimento ${ }^{3}$
}




\section{Resumo}

Este artigo discute alguns aspectos relacionados à representação e representatividade da mulher trans por meio do recurso cênico do travestismo nos palcos de São Luís (MA). Nesta historiografia destaca-se o recorte sobre uma territorialidade ainda pouco discutida no mapeamento dos espetáculos que focam os estudos de gênero no contexto do teatro brasileiro, reivindicando em sua investigação particularidades regionais de abordagem. Para isto, realizou-se um mapeamento de documentos históricos e entrevistas, deteve-se sobre a análise da manifestação popular $O$ auto do bumba meu boi (XIX), folguedo típico da cultura maranhense, além dos espetáculos Uma Linda quase mulher (1999), Travesqueens (2011) e Veronique (2015), os quais serviram de casos para uma investigação interessada em elencar mudanças relacionadas à apropriação de um discurso de representação à representatividade da mulher trans, na cena ludovicense em fins do século XIX até às primeiras décadas do século XXI, na capital maranhense.

Palavras-chave: Travestismo; poéticas queer; teatro do Maranhão; teatro ludovicense; representatividade trans

\section{Abstract}

This article discusses some aspects related to the representation and representativeness of the trans woman through the scenic resource of transvestism in the stages of São Luis (MA). In this historiography we highlight the clipping about a territoriality still little discussed in the mapping of the spectacles that focus the studies of gender in the context of the Brazilian theater, claiming in its investigation regional particularities of approach. For this, a mapping of historical documents and interviews was carried out, it was focused on the analysis of the popular manifestation. The auto do bumba meu boi (XIX), typical folklore of the Maranhão culture, besides the spectacles Uma Linda quase mulher (1999), Travesqueens (2011) ) and Veronique (2015), who served as cases for an investigation interested in the changes related to the appropriation of a representation discourse to the representativeness of the trans woman in the Ludovic scene at the end of the XX century and first decades of the XXI century in the capital Maranhão XX century, and first decades of the 20th century, in the capital of Maranhão.

Keywords: Transvestism; Queer poetic; ludovicense theater; trans woman; trans representativenes

\footnotetext{
${ }^{1}$ Expressão para designar pessoas naturais da cidade de São Luís (MA).

${ }^{2}$ Profa. Dra. Adjunta I - Curso de Licenciatura em Teatro da Universidade Federal do Maranhão (UFMA). (LabTecDrama). Professora colaboradora do Mestrado Interdisciplinar em Cultura e Sociedade (UFMA). Nandaareias1@gmail.com 
Este escrito aborda a historiografia do travestismo no teatro ludovicense de fins do século XIX e início do século XXI. Para isso, serão apresentadas quatro montagens que fazem parte deste panorama, as quais ilustram as diversidades de espetáculos que utilizaram desta prática artística no âmbito das artes cênicas em São Luís em diversos períodos históricos. Nestes espetáculos são apresentados discursos a respeito das questões de gênero, que refletem as relações de poder enraizadas no cotidiano sociocultural maranhense.

Portanto, descrevemos o recurso cênico do travestismo no teatro ludovicense para construir personagens femininas (mulheres cis e trans ${ }^{4}$ ) em diferentes estéticas teatrais e performativas, dando destaque às personagens femininas (travestis e transexuais) enquanto representação e representividade. Estes corpos que subvertem a ordem binária adentram à cena de São Luís (MA) em estéticas teatrais e performativas atreladas a discursos de representação e representividade de personagens trans em diferentes contextos históricos.

Os corpos queer (Delgado, 2013), os quais associamos aos estudos queer (Butler, 2003; Louro, 2016; Salih, 2015; Delgado, 2013), são construídos sobre as marcas do masculino, mas que almejam performativizar feminilidades. Corpos híbridos que borram as fronteiras discursivas de sexo, gênero e sexualidade, por isso são queer, que segundo Pereira Júnior (2016, p. 11-12) "ainda se encontravam silenciados na história teatral brasileira".

Este artigo é resultado da pesquisa monográfica intitulada Divas, Lindas, sintéticas ao natural: travestismo na cena teatral ludovicense (2017), aliada à coleta de dados da iniciação científica, na qual foram catalogados ${ }^{5}$ entre os anos de 2013 a 2015 vinte espetáculos teatrais, que representam montagens de fins do século XIX até a atualidade.

Entretanto, para este artigo serão apresentadas as seguintes montagens, as quais trazem um recorte historiográfico do travestismo em São Luís (MA), a saber: $O$ Auto do bumba meu boi, manifestação popular tradicional do Maranhão, com origens que remetem a segunda metade do século XIX, na qual a personagem Catirina, tradicionalmente representada por homens, exemplifica a técnica cênica do travestismo à luz das relações de poder, que segregavam as mulheres de participarem deste folguedo. Ressaltamos que este folguedo representa a montagem catalogada do século XIX, 0 qual atravessa o século passado e se mantém até a atualidade, como uma das principais manifestações culturais do estado do Maranhão.

\footnotetext{
4 "Cisgênero são pessoas cuja identidade de gênero está de acordo com o gênero que lhe foi atribuído ao nascer, correspondente à sua genitália (pênis ou vagina). Por exemplo, se uma pessoa nasce com uma vagina, provavelmente será educada para ser uma mulher, isso é, socialmente será generificada para agir, pensar e sentir como uma mulher. Caso essa pessoa de fato se entenda como mulher, então ela é cisgênero. Se, contudo, essa pessoa não se identifica como mulher, mas sim como homem, então será uma pessoa trans". (Lins; Machado; Escoura, 2016, p.124)

${ }^{5}$ Esta investigação foi desenvolvida em duas etapas. Primeiramente, como pesquisa de Iniciação Científica - PIBIC/UFMA, com o projeto Corpo e gênero: a construção discursiva da identidade não heteronormativa no teatro ludovicense, desenvolvida no Grupo de Pesquisa em Linguagem e Discurso do Maranhão (GPELD), vinculado ao departamento de Letras da Universidade Federal do Maranhão (UFMA), entre os anos de 2013 a 2015 . Neste período foram catalogados 20 espetáculos ludovicenses em que se percebeu o discurso da homoafetividade e travestismo (com ou sem discussões de gênero) na cena teatral de São Luís (MA) de fins do século XIX até a contemporaneidade. Inicialmente, a pesquisa objetivava verificar a construção discursiva da identidade homoafetiva (gay e lésbica), em seguida ampliaram-se as discussões, no segundo ano de pesquisa, para investigar como era "(des)construído" o corpo masculino para compor personagens femininas (mulheres cis e trans) sob o viés do travestismo. Posteriormente, entre 2016 e 2017 essa investigação transformou-se em pesquisa monográfica, na qual os dados foram selecionados para compor o acervo historiográfico do travestismo no teatro ludovicense.
} 
Outro trabalho analisado é Uma linda quase mulher (1999), espetáculo que apresentou personagens trans e expôs nos palcos maranhenses a marginalização das travestis prostitutas do Centro Histórico de São Luís (MA), sob o viés da comédia besteirol. Analisamos depois Travequeens (2011), o qual retrata os contextos de opressão e transfobia vivenciados pelas mulheres trans no cotidiano. Por fim, Veronique (2014), montagem que abordou a situação marginalizada desta travesti no Complexo Prisional do Carandiru, monólogo baseado no livro Estação Carandiru, de Dráuzio Varella, com adaptação para o teatro pelo dramaturgo Dib Carneiro Neto.

Estes últimos se destacaram no panorama do travestismo contemporâneo de São Luís por colocarem nos palcos mulheres trans e seus conflitos subjetivos e político-sociais através de representações e representatividades de pessoas transgêneras, as quais dialogam com os estudos queer. Para análise dos dados foram utilizadas entrevistas semiestruturadas com alguns artistas que participaram das montagens citadas, além de materiais de arquivos das companhias/artistas, matérias jornalísticas e críticas teatrais.

As discussões teóricas estão pautadas nos estudos de gênero, sobretudo queer a partir dos aportes teóricos de Judith Butler6 (2003), Guacira Lopes Louro (1997; 2016), Raewyn Connel e RebeccaPearse (2015), Luiza Cassemiro (2010), Sarah Salih (2015) em diálogo com autores/as que discorreram acerca do panorama do teatro maranhense, a saber: Aldo Leite (2007), Ubiratan Teixeira (2012), Tácito Borralho (2012), José Jansen (1974) e Abimaelson Pereira (2013), com o intuito de elucidar um novo cenário nos estudos teatrais de São Luís (MA), que foi silenciado no decorrer dos séculos: a historiografia do travestismo no teatro ludovicense atrelado à representação e representatividade de personagens trans.

O Bumba meu boi do Maranhão: travestismo na construção da personagem Catirina

A prática de travestir-se, enquanto representação de personagens femininas (mulheres cis) na historiografia teatral do Ocidente, sempre esteve presente desde a Grécia Clássica, quando as mulheres eram proibidas de interpretar papéis no teatro, sendo este recurso destinado aos atores (Rosenfeld, 2009; Lozano, 2013).

Em períodos históricos como o renascentista, conforme aponta Anatol Rosenfeld (2009, p. 171), ocorriam cenas nas quais os papéis femininos eram "representados por rapazes de cerca de 17 ou 18 anos, que se especializavam neles durante certo tempo, na extrema juventude. Apenas meados do século 16, uns 60 anos mais tarde, as mulheres vieram ao palco."

$\mathrm{Na}$ cena contemporânea, a prática do travestismo ainda prevalece como representação do feminino (mulheres cis e trans). Entretanto, a partir de discussões recentes acerca de protagonismo e representatividade ${ }^{7}$ de pessoas trans nas artes

\footnotetext{
${ }^{6}$ Neste artigo utilizamos como citação os nomes completos dos/as autores/as a fim de visibilizar as escritoras e teóricas, pois ao citar somente o sobrenome, conforme a ABNT, acreditamos que existe homogeneização dos sobrenomes das mulheres, haja vista que muitos estão caracterizados, gramaticamente, como masculinos, dando a entender que são autores. Por isso, quando citarmos nos parágrafos os autores e autoras iremos utilizar os nomes e sobrenomes.

${ }^{7}$ Recentemente o tema tem sido largamente discutido na impressa/mídia/redes sociais, como pode ser verificado nas seguintes matérias: Representatividade trans - MONART (Movimento Nacional de Artistas Trans, 2018), transfake em Gisberta - MONART (Movimento Nacional de Artistas Trans, 2018), A insurgência trans e seu alvo impreciso - Valência Losada (Losada, 2018), 'Gisberta', de Luis Lobianco: representação e representatividade nas artes - Paloma Franca Amorim (Amorin, 2018), Questões sobre a representatividade trans no teatro - Mateus Araújo (Araújo, 2018).
} 
cênicas, problematizam-se tais práticas a fim de agregar o debate político de artistas transgêneros à representatividade trans nos palcos e nos demais espaços de manifestações artísticas.

Recentes publicações também abordam os estudos queer e suas implicações na cena contemporânea no Brasil, como por exemplo, a tese intitulada Bonecas falando para o mundo: Identidades sexuais "desviantes" e teatro contemporâneo (2014), do pesquisador Rodrigo Dourado, a partir de análises dos espetáculos; a montagem brasileira Luís Antônio-Grabriela (2011) e a argentina Carnes Tolendas: retrato escénico de un travesti (2009), Rodrigo Dourado (2014) discutem como o teatro contemporâneo se apropria das histórias reais de travestis e transexuais para construir narrativas teatrais e performativas associadas a discursos queer.

$\mathrm{Na}$ contemporaneidade, artistas e companhias vêm discutindo as questões queer relacionadas ao corpo trans, através do travestimos enquanto representação, como por exemplo, o coletivo cearense - As travestidas. O coletivo nordestino, com direção de Silvero Pereira, é responsável por construir discursos poéticos queer sobre o universo trans, com montagens como Uma flor de dama (2004), Engenharia erótica - Fábrica de travestis (2010), Brtrans (2013), Quem tem medo de travesti? (2015), dentre outros.

Nos palcos paulistas o espetáculo Luís Antônio - Gabriela (2011), com direção de Nelson Baskerville, também se destaca por discutir sobre a transexualidade como representação de pessoas trans. Já no Sul do Brasil, destacamos o artista Ricardo Marinelli que, com a performance Não alimente os animais (2010), contribuiu para suscitar o debate queer nos festivais de teatro e dança no cenário nacional, ao colocar em cena a situação marginalizada em que vivem travestis prostitutas.

Diante destas discussões acerca do travestimento enquanto representação e representatividade trans na cena contemporânea, inicialmente é necessário distinguir o conceito de travestismo no teatro da construção identitária da travesti. O primeiro, como será apresentado no decorrer deste estudo, refere-se à prática artística na qual o ator se caracteriza com figurinos, maquiagens e acessórios, socialmente atribuídos ao gênero feminino (Trevisan, 2002; Trostoy; Lima, 2006). Em contrapartida, a travesti diz respeito a uma pessoa que nasce pertencente ao gênero masculino, porém se identifica com a identidade de gênero feminina, optando assim em adornar seu corpo para atingir atributos corporais característicos da construção social dada ao gênero feminino (Cassemiro, 2010). No entanto, sabe-se que nem todas optam pelo processo de hormonização para afirmarem-se como travesti.

Segundo o pesquisador Jorge Silvério Trevisan, no livro Devassos no paraíso: a homossexualidade no Brasil da colônia à atualidade (2002), no teatro brasileiro a prática do travestismo surge com os autos dos jesuítas, onde as personagens femininas eram interpretadas por homens, "como a personagem de uma velha na festa de São Lourenço, do padre José de Anchieta, representada pelos índios ainda no século XVI" (Trevisan, 2002, p. 216). Posteriormente, houve uma propagação do travestismo na cena teatral, sobretudo com a proibição das mulheres em interpretarem nos palcos.

Ainda conforme Jorge Trevisan (2002), os atores brasileiros se aperfeiçoavam na arte de travestirem-se de mulheres cis, justamente pela segregação destas nos palcos locais. No que tange ao contexto sociocultural de São Luís, a sociedade mantinha-se 
extremamente rígida quando se referia à participação de mulheres no teatro. Como destaca José Jansen (1974, p. 125), no século XIX em São Luís, as personagens femininas eram interpretadas por atores:

Todos sabem quanto rigorosos eram os preconceitos familiares que não viam com bons olhos estarem às meninas em palcos. Diante de tal impasse a solução salvadora era apelar para o travesti ${ }^{8} \mathrm{e}$, dessa forma entraram em cena muitos meninos que com o correr do tempo se tornaram homens notáveis como o caso de Aluízio de Azevedo já citado e Viriato Corrêa a quem davam os papéis de dama central, conforme o próprio contou-nos, bem humorado, em uma das agradáveis reuniões em casa do acadêmico Josué Montelo.

De acordo com o pesquisador José Jansen (1974), a sociedade ludovicense não fugia à regra e censurava a mulher em cena. Estas proibições eram reflexos das relações de poder e machismo que proibiam as mulheres de exercerem a profissão de atriz, pois as que optavam em seguir carreira artística eram difamadas perante a sociedade maranhense, sendo tratadas como prostitutas.

Neste sentido, essa censura que proibia as mulheres de participarem de espetáculos teatrais, também terá ressonâncias no folguedo mais popular do Maranhão, O Auto do bumba meu boi, mais especificamente com relação à personagem Mãe Catirina. O bumba meu boi, como discorre o professor e pesquisador Tácito Borralho (2012, p. 96), é uma "manifestação popular tradicionalmente representada nas festas juninas do estado. Tem suas origens mais primitivas em diversas culturas milenares". A personagem Mãe Catirina, por exemplo, desde o surgimento do auto, sempre foi interpretada por homens, sobretudo por brincantes que participavam dessa manifestação.

As primeiras apresentações, ainda no século XIX, eram realizadas por populares que organizavam a matança9 (Borralho, 2012). Para o pesquisador Tácito Borralho (2012, p. 303), a personagem de Catirina sempre fora rejeitada por parte dos brincantes. Como as mulheres não interpretavam personagens, sendo responsáveis apenas pela confecção dos figurinos e adereços, os homens tinham que representar todas as personagens, inclusive Catirina.

Dessa forma, a rejeição em interpretar uma personagem feminina refletia o contexto machista, sexista e misógino no qual este folguedo era representado. Acerca das relações de gênero nO Auto do bumba meu boi, Patrícia Lima e Lady Selma Albernaz (2013, p. 490-491), apontam:

Como uma brincadeira de caráter tipicamente masculino, esse folguedo possui práticas e significados de gênero que identificam, classificam e organizam os espaços de homens e mulheres, exercendo impactos na distribuição do poder, do prestígio e da riqueza que os desigualam. [...] No decorrer da observação, constatamos que este marcador de gênero opera em intersecção com o marcador racial, desdobrando-se em outras desigualdades.

\footnotetext{
${ }^{8}$ No decorrer da pesquisa verificamos que a prática/recurso do travestismo no teatro do século XIX era caracterizada como travesti, conforme é destacado na citação de José Jansen (1974). Entretanto, atualmente entende-se que a travesti é uma pessoa que se afirma com a identidade de gênero feminina, enquanto que o travestismo é o termo mais adequado para se referir a esse recurso cênico, bem como travestimento.

${ }^{9}$ Um dos termos para identificar $\mathrm{O}$ auto do bumba meu boi, além de folguedo e brincadeira, conforme destaca o pesquisador Tácito Borralho (2012). Importante ressaltar também que 0 auto do bumba meu boi refere-se à encenação teatral, enquanto 0 bumba meu boi trata-se da brincadeira, da manifestação cultural. (Borralho, 2012).
} 
Nesta perspectiva, Patrícia Lima e Lady Selma Albernaz (2013) relatam como as demarcações de gênero afetavam a organização e distribuições de homens e mulheres na matança, inclusive, citam que esse fator influenciava também as divisões dos papéis em que predominavam a participação de homens para interpretarem as personagens como: Amo do boi, Miolo do boi, Vaqueiro, Pai Francisco e Mãe Catirina. No que tange à personagem Catirina, por exemplo, as autoras apontam que:

\begin{abstract}
Outro personagem bastante polêmico do folguedo do boi é a Mãe Catirina. Durante muito tempo, esta foi uma posição ocupada apenas por homens, o que ainda se dá em alguns grupos de bois mais tradicionais, como os do interior do estado. Neste caso, o sentido de um homem representar uma mulher era entendido como algo cômico, engraçado, digno de ser feito por um bom palhaço. Porém, atualmente, esse posto já tem sido ocupado com frequência por mulheres, principalmente nos bois de orquestra. Some-se a isto também o fato de que em alguns bois já é perceptível a presença de homossexuais interpretando a Mãe Catirina. Devido a isso, muitos homens têm receio de que ao fazer o papel, no qual a presença de mulheres e homossexuais é bastante acentuada, sua orientação sexual heterossexual possa ser posta em dúvida. (Lima; Albernaz, 2013, p.501)
\end{abstract}

A rejeição por parte dos brincantes em interpretar a personagem Catirina tem relação, como destacam Patrícia Lima e Lady Selma Albernaz (2013), com o preconceito que os participantes sofriam por parte da sociedade, por acreditarem que a representação de uma personagem feminina afetaria a identidade sexual do brincante. As autoras apontam ainda que em entrevista realizada com um dos brincantes do boi sotaque ${ }^{10}$ de matraca, analisaram no discurso aspectos de rejeição por parte do ex-intérprete de Catirina, observaram também como o machismo afetava na aceitação dos participantes em interpretar esta personagem:

[...] tinha um homem que brincava [como Mãe Catirina, hoje em dia é uma menina]. Eu já fui convidado pra ser Mãe Catirina, eu é que não quis [...]. Eu acho bonito o que ela faz, só que pode ser que as pessoas não entendam. Eles não entendem, aí começam com aquelas críticas, aquelas coisas e eu... [...]. Não entendem o que é realmente a Mãe Catirina. Porque aquilo ali é um teatro que a gente tá fazendo, uma representação. Não que fique um homem em suspeição quando se veste de Mãe Catirina, mas as brincadeiras... o amigo já começa com umas brincadeiras mais pesadas, a pessoa não vai gostar, não diz nada, mas não está gostando. Aí pra evitar aborrecimento eu não aceitei. (Lima; Albernaz, 2013, p. 501 - grifos nossos)

Ainda que, conforme discorrem as autoras, na atualidade homens homossexuais e mulheres interpretem esta personagem, em grupo mais tradicionais ainda prevalecem brincantes homens, os quais se afirmam enquanto heterossexuais, geralmente de contextos sociais de cidades do interior do Maranhão, o que pode justificar as afirmações das pesquisadoras, haja vista os espaços de opressão e machismo no qual este folguedo é organizado no estado.

De acordo com Patrícia Lima e Lady Selma Albernaz (2013) a repressão da sociedade afetava diretamente na aceitação dos brincantes em interpretar Catirina,

\footnotetext{
${ }^{10}$ O pesquisador Tácito Borralho (2012) ressalta que esta manifestação popular é identificada através de sotaques, os quais dialogam com o tipo de música e instrumentos utilizados na brincadeira, além da caracterização de personagens. Dentre os sotaques de bumba meu boi destacam-se: sotaque de matraca, sotaque de zabumba e, mais contemporâneo, o boi sotaque de orquestra.
} 
pois a personagem exige do intérprete uma construção do feminino "[...] entendido como algo cômico, engraçado [...]" (Lima; Albernaz, 2013, p. 501). Sendo assim, o travestismo em Catirina (figura 1) é utilizado para atingir a comicidade, o riso, por meio do caricato, do estereótipo feminino travestido no corpo masculino, como representação burleca da mulher cis, negra, no contexto social humilde no interior do estado do Maranhão.

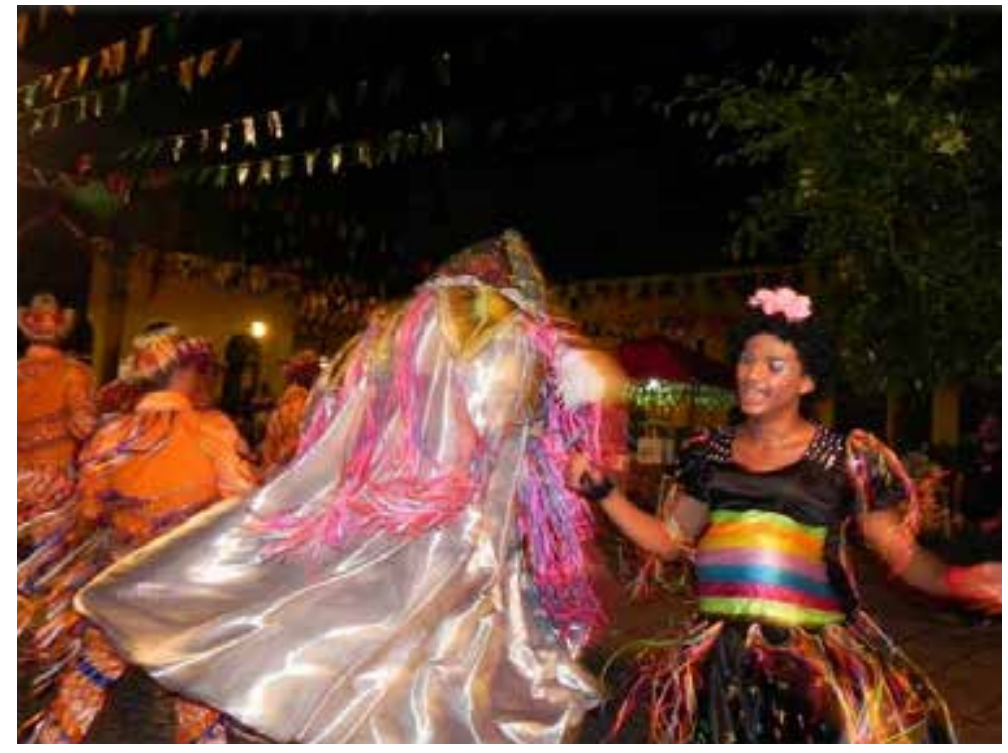

Figura 01 - Mãe Catirina e o boi Mimoso

Fonte: Arquivo do grupo Bumba-Boi Mimoso, 2015.

No auto, as personagens são caracterizadas através de intensa maquiagem ou máscaras, as máscaras representam personagens. Para compor Catirina o que prevalece é o estereótipo do feminino. Em todas as matanças, os brincantes se caracterizam almejando satirizar esse feminino da mulher cis. Na maioria das representações de Catirina, os brincantes constroem o estereótipo da mulher negra de forma caricata, com acentuada maquiagem, vestida com roupas coloridas, além de gestos que objetivam fazer a plateia rir.

Representação e representatividade da mulher trans na cena ludovicense: Uma linda quase mulher (1999), Travesqueens (2011) e Veronique (2014)

$\mathrm{Na}$ historiografia do travestismo no teatro ludovicense de final do século XX, destaca-se o espetáculo Uma linda quase mulher (1999), montagem que representa um grande marco no percurso do travestimento nos palcos locais, por introduzir personagens travestis, ainda que a partir da representação por atores cis gêneros, abordando a realidade político-social destas no cotidiano de São Luís (MA).

No final da década de 1990, estreia nos palcos o espetáculo Uma linda quase mulher (1999), pela Cia Deixa de Bobagem, com texto e direção coletiva, além de concepção final de Denilton Neves. O espetáculo ficou em cartaz em temporadas temáticas por 15 anos. Sua dramaturgia é uma sátira do filme hollywoodiano - Uma linda mulher, sucesso na década de 1990. 
Na montagem ludovicense o enredo discorre sobre o casal de protagonistas: Júlia Roberta e Ricardo Gerardo. Júlia é uma empregada doméstica, interpretada pelo ator Denilton Neves, que sai da Maiobinha, bairro da periferia de São Luís, para trabalhar na casa de uma madame falida, Aurijane Eliglantine. No decorrer da peça, Júlia tenta sobreviver em meio às peripécias organizadas pela vilã Cíntia Sapequara, interpretada pelo ator Erivelto Viana, e sua patroa Aurijane Eliglantine, interpretada pelo ator Guilherme Telles.

Quanto ao espetáculo (figura 2), o crítico de teatro Ubiratan Teixeira (2012) afirma que "não é nada mais, nada menos do que um autêntico besteirol"; acrescenta ainda que o espetáculo faz jus a sua proposta cênica de humor escrachado "[...] e é como peça do gênero e rigidamente datada que tem que ser vista - e sem preconceito, pois o elenco não pede nada mais do que isso" (Teixeira, 2012, p. 178).
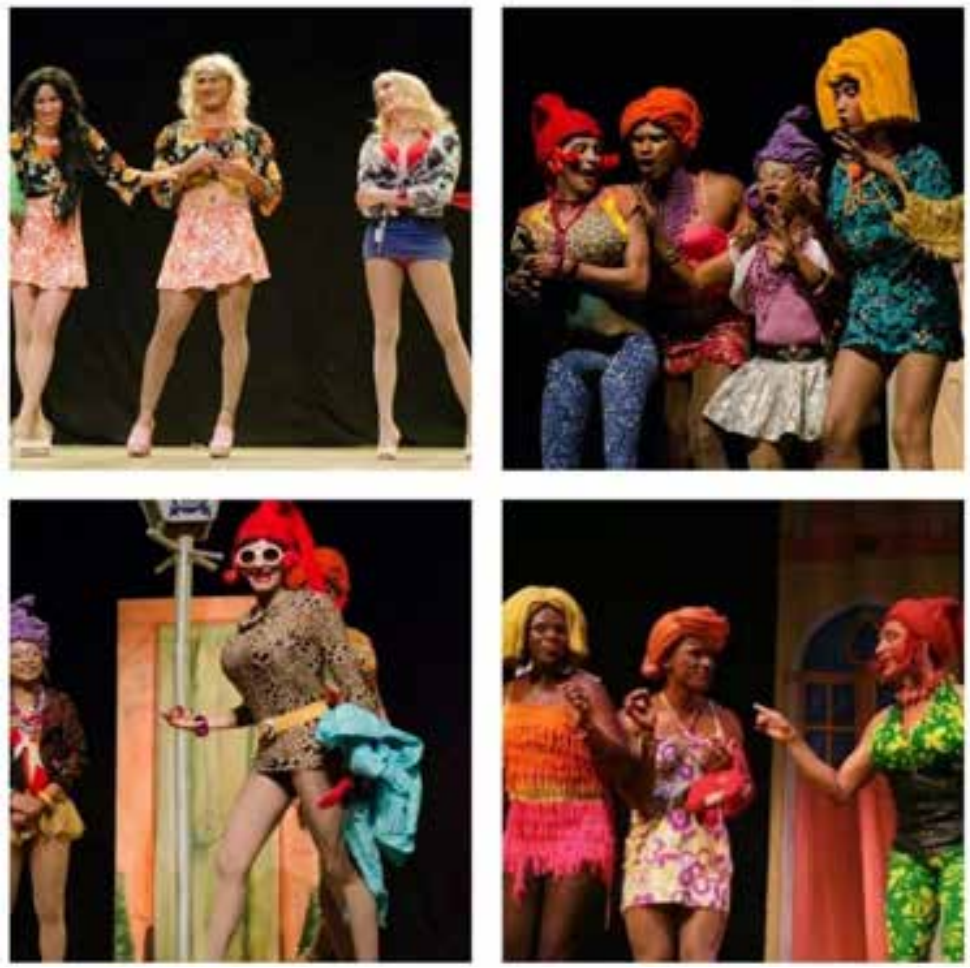

Figura 02 -Cena de Uma linda quase mulher

Fonte: Fotomontagem elaborada pelos/as autores/as a partir de imagens pesquisadas no Google.

De acordo com Ubiratan Teixeira (2012, p. 179), a Linda (1999), através do gênero dramático besteirol, é uma "sátira política e social". Em paralelo, observa-se que a história de amor entre os protagonistas é pano de fundo para representar papéis sociais, reforçar a luta de classes, o racismo, a situação marginalizada das travestis na cidade de São Luís (MA), bem como satirizar a sociedade e a política ludovicense, tudo isso, claro, com muito humor, de forma muito expositiva, característica deste gênero dramático.

Erivelto Viana, ator que interpreta Cíntia Sapequara, descreveu em entrevista para esta pesquisa que o início do que viria a ser, posteriormente, o espetáculo Uma linda quase mulher (1999), surgiu do contato entre parte do elenco, que trabalhava na companhia do diretor Fernando Bicudo, na época diretor do Teatro Arthur Azevedo: 
A gente era do Teatro Arthur Azevedo [...] a gente entrou no teatro, na época em 94, então, foi à época que Fernando Bicudo chegou aqui em São Luís e o teatro Arthur Azevedo reinaugurou em 93 [...] E aí alguns artistas já faziam teatro, outros, balés, pela cidade; e houve uma grande seleção para o corpo de baile do teatro, com a montagem de O sonho de Catirina [...] Aí que conheci o Denilton (Denilton Neves), que veio pra cá para trabalhar no teatro Arthur Azevedo, e ele teve uma experiência com aquela peça de Recife Cinderela: a história que sua mãe não contou, muito famosa por lá [...]. (Erivelto Viana, 2017)

O espetáculo Cinderela: a história que sua mãe não contou, citado por Erivelto Viana, estreou em setembro de 1991, no Teatro Valdemar de Oliveira no Recife - PE, sob o viés dramático do gênero besteirol, como descreve Luís Reis (2002). O espetáculo discutia problemáticas políticas e sociais presentes na sociedade brasileira, em especial, no contexto recifense.

Assim, como na montagem pernambucana, o espetáculo maranhense através do mesmo gênero teatral, também colocou em cena os estereótipos típicos do contexto local, a saber: as travestis (que na encenação são identificadas como "viado" e qualira"1) que trabalham nas ruelas e becos do Centro Histórico, nas Avenidas Guajajaras e São Luís Rei de França, localizadas em bairros da capital maranhense. Estas expressões pejorativas, representadas na montagem, contextualizam a sociedade ludovicense a qual deslegitima a identidade de gênero feminina das travestis, insistindo em nomeá-las com expressões e xingamentos no masculino, a exemplo de "traveco".

Em Uma linda quase mulher (1999), o cenário foi ambientado no Centro Histórico de São Luís (MA) para representar a prostituição das travestis locais, a empregada doméstica, o cobrador de ônibus, a mãe de santo, dentre outros/as personagens que permeiam o cotidiano maranhense.

Para Erivelto Viana, as travestis tinham uma comicidade e ao mesmo tempo viviam em situações marginalizadas no Centro Histórico, estas foram as inquietações que inspiraram o elenco a representá-las nos palcos. Além das boates, o cotidiano e, principalmente, a noite ludovicense, foram ambientes ilustrados em Uma linda quase mulher (1999), o que se verificou como importantes para mostrar na cena local a situação marginalizada das travestis que trabalham como prostitutas, e, então, iniciar discursos queer de visibilidade da identidade trans ainda no final do século passado. Acerca do processo de pesquisa e observação das travestis, Erivelto Viana (2017) enfatiza que:

Depois da peça a gente trouxe essas observações que a gente tinha feito antes de começar a peça e voltou lá para observar mais no caráter do espetáculo. A gente morava aqui no Centro, sempre morou, e tinha muitas travestis que faziam programa por aqui.

\footnotetext{
${ }^{11}$ Expressão linguística tipicamente ludovicense para designar o homossexual masculino, na grande maioria das vezes, de forma pejorativa e preconceituosa. Esta expressão tem origem conforme ThercianeSilveira e Conceição Ramos (2012) no "[...] termo que há tempos foi de uso exclusivo dos maranhenses, mas que, em função da atuação da mídia e do uso contínuo, acabou por se tornar conhecido em nível nacional. [...] o vocábulo qualira teve origem no Centro Histórico de São Luís, onde habitava um homem que andava com uma lira e que costumava passear por essa região. Então, toda vez que ele passava as pessoas costumavam dizer "lá vem o homem com a lira". Daí ocorre o fenômeno que se chama de corruptela na expressão "com a lira" que passou a ser "qualira". Como os gestos realizados pelo tocador da lira eram delicados, as pessoas começaram a designar o homossexual por esse vocábulo. (Silveira; Ramos, 2012, p. 2651).
} 
No que tange às discussões em Uma linda quase mulher (1999), dentre as temáticas abordadas, destacam-se: opressão de classes sociais (representada pelo embate entre a protagonista e sua patroa), a marginalização e o preconceito sofridos pelas travestis na prostituição (sendo representadas nas personagens travestis prostitutas), os padrões discursivos e estereotipados de beleza (representados na cena do concurso de beleza), o preconceito racial e sexual (destacado em diversas piadas machistas e preconceituosas proferidas entre as personagens durante o desenrolar da trama), dentre outras. Sobre o processo criativo de construção do texto e estreia da Linda (1999), Erivelto Viana (2017) descreve que:

\footnotetext{
A gente estreou a Linda em outubro ou novembro de 1999 [...]. Aí, falamos, vamos fazer uma peça [...] Eu e Fábio, um amigo nosso, começamos a escrever um monte de bobagens [...]. Até que em 1999 Denilton chamou: vamos, vamos fazer, e fizemos na boa, na sala dele, começamos a ensaiar. Os personagens não tinham nem sobrenome [...]. Eu só sabia que ia fazer a Cíntia e ela era vilã da peça.
}

Posteriormente, relatou Erivelto Viana em entrevista, que o espetáculo estreou, inicialmente, com pouquíssimo público no Circo da Cidade. A Linda (1999) realizou poucas apresentações naquele ano, retornou aos palcos em 2000, cada ano conquistando mais sucesso de público. A estreia da parte 2 de Uma linda quase mulher, na qual o enredo se desenvolvia em torno da misteriosa morte da vilã Cíntia Sapequara, continuou com sucesso nos palcos ludovicenses. No decorrer dos anos 2000, 0 espetáculo sempre se reinventava e trazia novas esquetes de acordo com as datas comemorativas e festividades regionais.

No ano de 2015 ocorreu a última temporada comemorativa de 15 anos na cena teatral de São Luís. De modo, como ocorrido com o espetáculo pernambucano Cinderela: a história que sua mãe não contou (1991), o qual inspirou a montagem de Uma linda quase mulher (1999), a classe artística e até mesmo os espaços teatrais não valorizaram o teatro realizado pela Cia Deixa de Bobagem, em grande parte da trajetória da montagem, como destacou Erivelto durante a entrevista. Todavia, aos poucos, o espetáculo foi ganhando notoriedade na cena e na mídia maranhense e tornou-se sucesso de público no decorrer dos 15 anos que permaneceu em cartaz.

O destaque para as discussões sobre as relações de gênero, sobretudo acerca da representação e representatividade das mulheres trans na produção dramatúrgica e teatral, a partir do ano de 2010, terá mais notoriedade na historiografia da cena ludovicense; a partir deste momento o recurso do travestismo também será utilizado para construir narrativas que problematizam sobre a realidade social e a subjetividade de personagens trans através do que apresentamos como poéticas queer.

Para isto, destacamos uma cena contemporânea na qual o travestismo está associado à representação e representatividade das mulheres trans no teatro de São Luís. Neste contexto os estudos de gênero e sexualidade repercutem com mais vigor na universidade, fomentando a pesquisa e a produção teórica, estabelecendo diálogo entre teatro e gênero, no qual artistas, dentro e fora da academia, iniciaram novas propostas de poéticas queer na cena contemporânea de São Luís. 
Assim, os/as artistas, dentro e fora da academia, iniciaram novas propostas de poéticas queer nas artes cênicas contemporânea de São Luís (MA), tais poéticas segundo Abimaelson Pereira (2013, p. 51):

Relacionam-se com temáticas como espaço urbano, territorialidade, identidade, memória, gênero, entre outras, e discutem tanto sobre as modificações culturais das cidades, quanto exercem uma relevante influência na maneira de se pensar o fazer teatral na pós-modernidade.

Dessa forma, estabelecemos diálogos teóricos entre as poéticas contemporâneas da cena ludovicense propostas pelo pesquisador maranhense Abimaelson Pereira (2013) com os estudos Queer segundo Judith Butler (2003), Sarah Salih (2015) e Pedro Delgado (2013), a fim de apresentar de que forma as montagens, Travesqueens (2011) e Veronique (2014), constroem discursos de gênero e sexualidade, a partir da estrutura dramatúrgica e da caracterização de personagens trans, acerca da representação e representatividade de mulheres trans na cena contemporânea.Pois ao discorrerem sobre os corpos queer, deslocados e subversivos se correlacionam com as representações e representatividades das identidades trans na historiografia do travestismo ludovicense.

Estes corpos subversivos, que agora adentram, oficialmente, à cena maranhense aparecem deslocados do centro de um teatro heteronormativo, no qual o travestismo era a representação de personagens femininas (mulheres cis) conforme apresentado com o folguedo $O$ Auto do bumba meu boi.

Dessa forma, no atual contexto cênico os corpos queer (Butler, 2003; Louro, 2016; Delgado, 2013) que serão apresentados, são deslocados e subversivos desconfigurando as normas binárias que até então permeavam o teatro ludovicense, já que agora ecoam outras vozes de sujeitos que não tinham visibilidades na historiografia teatral local e que reivindicam falar de si, reivindicam o direito de serem protagonistas dos seus próprios discursos, cujas identidades pertencem aos/as personagens LGBTI's $^{12}$ (Lésbicas, Gays, Bissexuais, Travestis, Transexuais, Transgêneros e Intersexuais), principalmente as travestis e transexuais. O corpo queer, conceito que advém dos estudos queer, surge, de acordo com o pesquisador Pedro Delgado (2013, p. 23), com o:

Pensamento dos teóricos queer, é possível chegar à conclusão de que a teoria Queer apresenta um campo semântico provocante, composto por vocábulos como reconversão, deslocamento, reconfiguração, desnaturalização, subversão, performatividade, paródia, etc. Muitas dessas expressões são tropos que indicam movimento e transformação, assinalando que algo muda após o ato performativo de transformar um insulto numa forma orgulhosa de identificação.

\footnotetext{
${ }^{12}$ Segundo Beatriz Lins, Bernardo Machado e Michele Escoura (2016), a sigla LGBTI estão sempre em processo de transição, pois conforme discorrem "é preciso dizer que o movimento LGBT, bem como as pessoas que ele representa, estão em contínuo processo de mudança. No início dos anos 1990 no Brasil, por exemplo, a sigla mais utilizada era GLS - Gays, Lésbicas e Simpatizantes. Ao longo dos últimos anos, novas demandas por reconhecimento de especificidades e de sujeitos que se sentiam invisíveis ou até excluídos fez a sigla ser modificada. Portanto, as letras se alteram de acordo com o momento político e as respostas que os movimentos sociais dão para as demandas e questões que emergem nos diferentes contextos históricos. No momento da publicação desta edição, boa parte dos movimentos sociais e do poder público assume a sigla LGBT para se referir à comunidade de Lésbicas, Gays, Bissexuais, Travestis e Transexuais, por esse motivo a manteremos neste livro. Pode ser que novas transformações sociais alterem a formação das siglas ou o rumo das demandas deste grupo exigindo desta publicação uma constante atualização para melhor dialogar com o movimento (Lins; Machado; Escoura, 2016, p. 11). Atualmente, verificamos o uso da sigla LGBTI, com inserção do "I" para representar as pessoas intersexuais, anteriormente identificadas como hermafroditas. Será esta sigla que utilizaremos neste estudo, uma das atuais siglas do movimento.
} 
O termo queer que outrora fora um insulto para representar os gays nos Estados Unidos, foi ressignificado e apropriado naquele país, assim como em outros países, para transformar-se "numa forma orgulhosa de identificação" (Delgado, 2013, p. 23). Queer, que anteriormente era um termo pejorativo, torna-se uma expressão e ato de empoderamento político e social.

Esta noção aparece na cena ludovicense associado ao corpo queer, que protagoniza poéticas queer sobre discursos políticos e de gênero na representação e representatividade de personagens travestis e transexuais. Logo, o conceito de queer foi também apropriado nesta investigação como discurso subjetivo do artista, enquanto LGBTI, cujas vivências subversivas na prática social constroem obras com proposta transgressiva e deslocada da matriz heterossexual, que nas nossas associações teóricas também dialogam com estes estudos. Como destaca Pedro Delgado (2013, p. 26) esse corpo Queerizado:

Está sempre em estado de devir-outro que borra as fronteiras e lugares. O corpo queerizado, em geral, quando está em cena, tem um peso de contaminação afetivo. Ocupa o imaginário porque se apresenta como um campo fértil, porque rompe em corpos possíveis, em devires inesperados, em riscos, em possíveis totalidades que também estão prontas para desaparecerem ou se modificarem num instante qualquer, subvertendo a ordem vista até então como uma "verdade". Sua presença é apenas a ausência pouco segura de um comportamento cultural e ético-social.

Ratifica-se que a ideia aqui trazida para discussão de poéticas queer, termo ainda em processo de desenvolvimento nas pesquisas por ora realizadas, se compreende como narrativas da cena contemporânea que são criadas através de teatralidades e performatividades com ênfaseno protagonismo da mulher trans, corporeidade Queer/trans, aspectos que reverberam em poéticas queer de visibilidade e representatividade da figura trans com suas implicações subjetivas e/ou político-sociais nos espetáculos.

\section{Poéticas queer em Travesqueens (2011): representações de corpos trans}

A cena contemporânea em São Luís (MA) apresenta corpos queer, ilustrados nas seguintes montagens por meio das personagens de Travesqueens (2011) e Veronique (2014), os quais assemelham-se a desviantes, flutuantes, inquietantes, perturbadores e por isso transgridem as normas de corpo, sexo, gênero e sexualidade dentro de uma lógica normativa, de uma cena heteronormativa que marcava o panorama do teatro no Maranhão.

Dessa forma, a partir dos anos 2000 muitos artistas e discentes/pesquisadores/ as saem do estado do Maranhão para estudar teatro, ao retornarem com novas discussões e percepções estéticas da cena contemporânea, compartilham-nas e as difundem no teatro local, seja através de montagens, seja na organização de eventos artístico-culturais e/ou residências artísticas.

Dentre os/as artistas que vivenciaram este processo, dar-se-á destaque para Erivelto Viana ${ }^{13}$, que após realizar residências artísticas, cursos, participar de festivais

\footnotetext{
${ }^{13}$ Artista, produtor e arte-educador. Desenvolve projetos e articulações para a dança, teatro e performance que integram o BemDito Coletivo (MA). Desde 2008 realiza em São Luís o Festival Conexão Dança.
} 
e mostras de teatro/dança fora do estado do Maranhão, teve contato com propostas teatrais e performativas, pesquisas em teatro, dança e performance. Além de ter vivenciado experiências com artistas, performers e pesquisadores/as de gênero e sexualidade na cena contemporânea, discutindo principalmente sobre as mulheres trans, como este afirmou em entrevista:

Eu tive contato com Ricardo Marinelli que já pesquisava gênero, eu, até então, não tinha um entendimento de gênero. [...]. Eu convido o Marinelli para participar do Conexão Dança, aí ele me vê de Cíntia e adora. Em 2010, o Marinelli convida eu e o Elielson, que é de Teresina, para realizarmos um projeto juntos. (Erivelto Viana, 2017)

Segundo Erivelto foi através do artista Ricardo Marinelli que iniciou seus estudos a respeito das discussões de gênero na cena. Os três artistas dos estados do Paraná, Maranhão e Piauí já desenvolviam montagens com suas respectivas personagens, mas foi por meio da parceria para o processo de montagem de Travesqueens (2011) que as personagens se encontraram para visibilizarem e performarem poéticas queer dos corpos trans marginalizados nas capitais de São Luís (MA), Curitiba (PR) e Teresina (PI).

Os artistas (cis gêneros) representam personagens transexuais em diversos contextos sociais do Brasil, entre as cidades de Curitiba (PR), São Luís (MA) e Teresina (PI). Em Travesqueens (2011), os corpos das mulheres trans potencializam, através de estéticas performativas, problematizações sobre o universo das travestis brasileiras que sofrem, cotidianamente, as marcas da transfobia.

De acordo com Erivelto Viana, após o diálogo entre os artistas, surge a proposta de concepção do espetáculo Travesqueens (2011). No qual o processo criativo deu-se da seguinte forma:

Nós ganhamos o prêmio Klaus Viana e realizamos a montagem de Travesqueens que estreia no Rio de Janeiro, mas depois é apresentado em São Luís, Curitiba e Teresina. É um espetáculo de dança, aqui já se discute a situação da travesti. A gente já começa a falar das travestis de Teresina que é um dos estados que mais tem assassinatos de travestis. É um espetáculo de performance, um espetáculo híbrido. (Erivelto Viana, 2017)

Como frisa Erivelto, as questões sobre as travestis ganham notoriedade e discurso intencional em Travesqueens (2011). Nessa montagem, foi identificado no curso das pesquisas que o protagonismo das mulheres trans na historiografia cênica de São Luís começa a ter visibilidade, iniciando com reflexões sobre a realidade destas, em uma proposta poética performativa (Féral, 2009). O artista destacou que além das discussões sobre as travestis, Travesqueens (2011) “[...] é um espetáculo de performance, um espetáculo híbrido", ou seja, uma proposta que será característica da cena contemporânea ludovicense, como ressalta Abimaelson Pereira (2013, p. 20):

Os grupos e artistas começaram a explorar as possibilidades de uma cena híbrida, seja ela pensada enquanto confluência de linguagens artísticas ou como uma investigação heterogênea dos elementos da encenação. Começou-se a utilizar a dança, as artes visuais e a música como forma de expressão que se interligam de maneira orgânica com os elementos do teatro. 
Em Travesqueens (2011), por exemplo, ressalta-se como um espetáculo híbrido, com um discurso político de gênero sobre as mulheres trans, contribuiu para uma poética queer performativa (figura 3). No elenco, encontram-se Erivelto Viana como Cíntia Sapequara, Elielson Pacheco como Soraya e Ricardo Marinelli como Princesa Ricardo. Nesta cena contemporânea na capital maranhense, Abimaelson Pereira (2013) afirma que o diálogo entre as diversas linguagens artísticas será uma constante nas montagens.

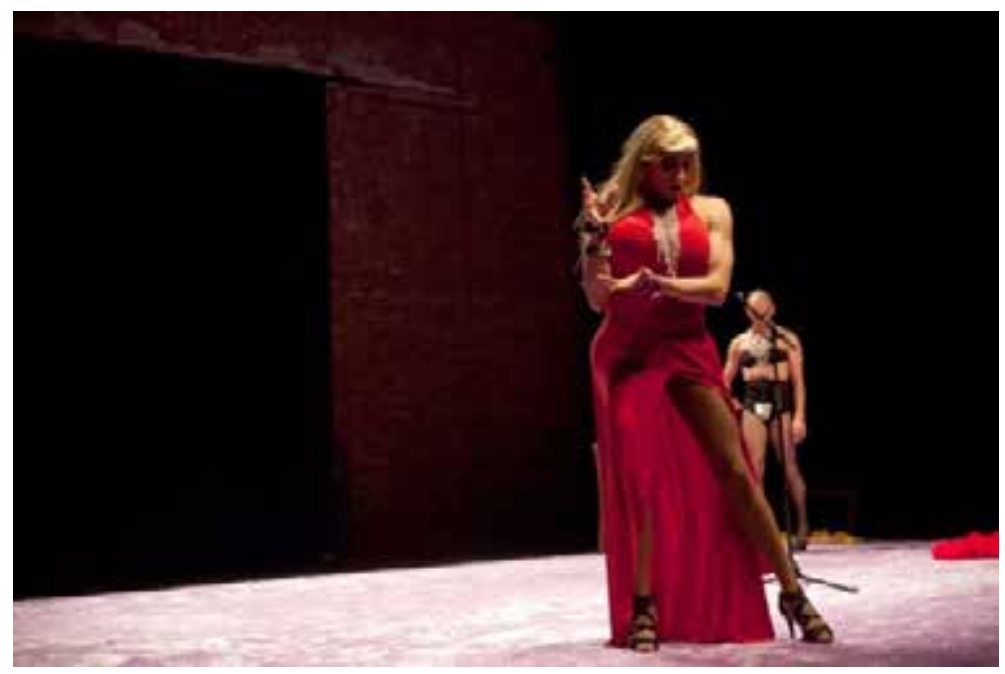

Figura 3 - Travesqueens

Fonte: Pedro Munis, 2011.

A partir de Travesqueens (2011), percebem-se montagens na cena ludovicense nos quais corpos queer, como os das personagens travestis Princesa Ricardo, Cíntia Sapequara e Soraya, dialogam com os vocábulos que segundo Pedro Delgado (2013, p. 23) surgem com os estudos queer. Cíntia Sapequara, por exemplo, em Travesqueens (2011), está inserida no contexto de uma poética queer que aborda a situação das travestis em diversos estados brasileiros, numa montagem com elementos da dança contemporânea, performance e teatro performativo (Féral, 2009). Assim, Cíntia, Soraya e Princesa Ricardo são representações de corpos queer.

Neste sentido, para Pedro Delgado (2013) o corpo queerizado borra as binaridades, as fronteiras da heteronormatividade. Nesta linha de análise identifica-se que o queer se apresenta em Travesqueens (2011) a partir do sujeito e suas vivências como corpos LGBTI's e suas práticas teatrais e performáticas serão construídos cenicamente a fim de criar novos discursos sobre as mulheres trans na cena contemporânea de São Luís (MA), oportunizando reescrever na historiografia maranhense um panorama do travestismo que dá visibilidade à identidade trans.

\section{Poéticas queer em Veronique (2014): a representatividade trans entra em cena}

A historiografia do travestismo no teatro ludovicense terá novos contornos poéticos e discursivos a partir da estreia do espetáculo Veronique (2014). A montagem foi o memorial de conclusão de curso da atriz e professora de teatro Liah Ramos no curso de Licenciatura em Teatro da Universidade Federal do Maranhão (UFMA). 
O texto original foi inspirado no best-seller Estação Carandiru, do autor Dráuzio Varella, com adaptação para os palcos pelo dramaturgo Dib Carneiro Neto em 1999, com o título Salmo 91. Na peça Salmo 91 o dramaturgo narrou histórias de personagens como: o malandro Dadá, o romântico Charuto, o enfermeiro Edelson, Valente, as travestis Zizi Marli e Veronique, dentre outros/as, os quais compõem monólogos que se entrelaçam e expõem o cotidiano do Complexo do Carandiru.

No espetáculo ludovicense o processo de travestimento no qual se constrói uma performatividade feminina está atrelado ao que verificamos como representatividade na cena teatral de São Luís, haja vista que a atriz Liah Ramos é transexual. A atriz ainda nas primeiras apresentações desta montagem, entre os anos de 2014 a 2016, se afirmava enquanto homossexual e, posteriormente, se afirmou como mulher trans. Dentre as montagens catalogadas Veronique (2014) é a única na qual uma artista transexual protagoniza a cena, entrelaçando as narrativas ficcionais com a representatividade de uma artista trans.

De acordo com o pesquisador argentino Ezequiel Lozano, no artigo intitulado Performatividad de Género y Travestismo a través de Escenificaciones de Las Criadas de Genet (2013), no qual analisou espetáculos que apresentaram o recurso do travestismo em montagens da peça As criadas, de Jean Genet, investigou as diferenças “[...] entre unempleoestetizante de este recurso escénico, un uso cuestionadory otroparódico" (Lozano, 2013, p. 806). O autor também se fundamentou nos estudos queer para analisar os espetáculos, ressaltando que historicamente homens e mulheres cis utilizaram essa prática no panorama teatral mundial, destacando que:

En los escenarios porteños se pueden rastrear numerosos ejem $\neg$ plos de travestismo, y ello ocurre mucho antes de que las personas transingresen a los escenarios. Hablamos aquí de casos repetidos de actores y actrices que llevan el travestismo a la escena teatral. (Lozano, 2013, p. 806)

O autor aponta para o que discorremos no decorrer deste artigo, o recurso do travestismo enquanto representação de personagens trans em São Luís (MA). Entretanto, destacaremos neste subcapítulo o uso desta prática enquanto representatividade de pessoas trans em cena, conforme destacado na montagem de Veronique (2014).

Neste sentido, conforme discorre o autor Ezequiel Lozano (2013), sua investigação baseou-se "[...] en los estudios queer, enaltecemos la potencialidad política del travestismo cuestionador, puesto que intenta convertirse enun signo teatral desestabilizador del binarismo de género hete $\neg$ ronormado" (Lozano, 2013, p. 806). Assim sendo, também em diálogo com Ezequiel Lozano (2013), compreendemos que o recurso do travestismo associado aos estudos queer destabiliza as práticas normatizavas e binárias na cena teatral, possibilitando o compartilhamento de narrativas LGBTI's, por meio do que percebemos como poéticas queer de representação e representatividade do corpo trans na cena teatral de São Luís.

Dessa forma, em nossas análises a atriz transexual Liah Ramos, ao interpretar a travesti Veronique, desestabiliza as normas binárias de sexo, gênero e sexualidade, como discorre Judith Butler (2003), quando problematiza os engradamentos nos quais o corpo da travesti perpassa ao vivenciar uma performatividade de gênero não 
heteronormativa. Portanto, para a autora, o corpo da travesti desestrutura as normas binárias de gênero ao problematizar que:

\begin{abstract}
Se a verdade interna do gênero é uma fabricação, e se o gênero verdadeiro é uma fantasia instituída e inscrita sobre a superfície dos corpos, então parece que os gêneros não podem ser nem verdadeiros nem falsos, mas somente produzidos como efeitos da verdade de um discurso sobre a identidade primária e estável. Em Mother Camp: FemaleImpersonators in America ["Meneirismos da mamãe: as travestis da América"], a antropóloga Esther Newton sugere que a estrutura do travestimento revela um dos principais mecanismos de fabricação através dos quais se dá a construção social do gênero. Eu sugeriria, igualmente, que a travesti subverte, e zomba efetivamente do modelo expressivo do gênero e da ideia de uma verdadeira identidade do gênero. (Butler, 2003, p. 195, grifos nossos)
\end{abstract}

Em conformidade com Judith Butler (2003), a travesti subverte a noção fixa de gênero, propõe que o gênero, assim como a sexualidade é fluída e transgressora, uma construção social. A autora problematiza a ideia fixa dos engendramentos dos corpos e discorre acerca das possibilidades nas quais cotidianamente construímos performatividades de gênero.

Portanto, na montagem ludovicense as narrativas da travesti Veronique são atravessadas pelas experiências da atriz transexual Liah Ramos (ainda que não estejam explícitas na dramaturgia e na encenação). Ambas carregam nos corpos, as marcas da performatividade de gênero (Butler, 2003) e com elas a transfobia, por isso compartilham experiências que as colocam no cerne do travestismo enquanto representatividade trans.

A partir do desenvolvimento do monólogo de Veronique são dados elementos discursivos do cotidiano penitenciário do Carandiru no qual verificamos como o machismo e a transfobia atravessam os corpos das pessoas transexuais que vivem naquele espaço repressivo e binário.

No início, Veronique (figura 4) relata de que forma seu corpo foi modelado com cimento, pois não tinha condições financeiras para iniciar seu processo de transição para o gênero feminino. Esta é a realidade de grande parte das travestis que optam pelo processo de harmonização no Brasil, mas que no entanto não conseguem o acompanhamento pelo sistema público de saúde, denunciado na dramaturgia pela protagonista. Entretanto, é importante destacar também, que nem a todas pessoas trans almejam modificarem seus $\operatorname{corpos}^{14}$.

\footnotetext{
${ }^{14}$ De acordo com Beatriz Lins, Bernardo Machado e Michelle Escoura (2016) "transexuais/travestis/transgêneros são pessoas cuja identidade de gênero é diferente daquela esperada para seu corpo: indivíduos nascidos com pênis que têm autoimagem feminina; ou aqueles nascidos com vagina que têm autoimagem masculina." (2016, p. 130). Entretanto, há pessoas trans não binárias, ou seja, que não se identificam nem com o gênero feminino, nem masculino, isso implica frisar que não seriam os estereótipos corporais socialmente atribuídos ao "ser homem" ou "ser mulher"/performatividades de gêneros masculino e feminino, que identificariam essa pessoa enquanto trans.
} 

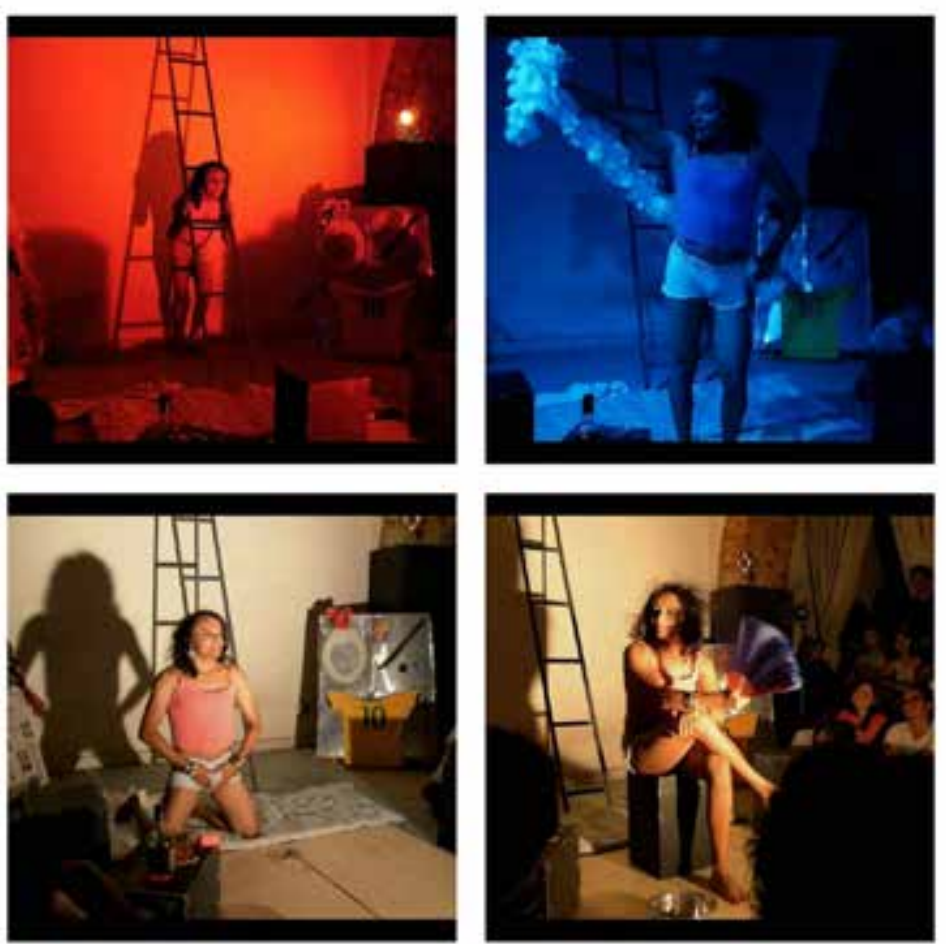

Figura 04 -Veronique

Fonte: Fotomontagem elaborada

pelos/as autores/as a partir de imagens disponibilizadas pela atriz, 2018.

No que tange à cena, o contexto carcerário auxilia na compreensão de como o corpo de Veronique sofreu os suplícios que geralmente acontecem neste espaço. Durante o espetáculo a protagonista discorre que, ao ser presa, fora torturada pelos policiais sofrendo um processo de "desfeminilização".

Dessa forma, em uma sociedade heterormativa, binária, sexista e transfóbica, representada metaforicamente pelo contexto carcerário no qual a protagonista se encontra, seu corpo transgride as normas de sexo/gênero/sexualidade (Butler, 2003). Sendo assim, a primeira tática coercitiva (Foucault, 1987) para disciplinar e normatizar o corpo trans nos presídios é a "desfeminilizá-lo", "regressá-lo" ao processo biológico e binário no qual estava inserido, antes de afirmar sua performatividade de gênero feminina, assumindo-se como transexual.

O suplício do corpo trans no ambiente penitenciário através de violência física e verbal visa descaracterizar e desconstruir o feminino almejado por esta. Em uma das passagens do espetáculo a protagonista denuncia o preconceito que sofreu por transgredir as normas binarias da heteronormatividade, ao assumir-se travesti:

Tamo aqui mesmo sem fazer nada, sem sabê direito até quando, nem porque viémopará aqui, sem matá, sem roubá, só porque é bicha, só porque um dia resolve encher os peito, meter a saia agarrada e sair pras esquina... Pronto, baixa os polícia e a gente vira "elemento perigoso"...Ai que nojo! Elemento é o cu deles, que às vezes a gente tem de comer também, te contei, não? (Veronique, 2014)

O espetáculo Veronique (2014) denuncia o preconceito que a sociedade tem contra as travestis, apontando também um sistema penitenciário falho, no qual indivíduos sobrevivem amontados em celas fétidas e sem higiene. 
A montagem problematiza também a marginalização sofrida pelas travestis, por outro lado mostra como o palco ludovicense pode romper com os discursos que até então se enraizavam em torno da figura da travesti no teatro de São Luís, sempre representadas estereotipadas. Veronique, ao expor suas mazelas, anseios e aflições torna-se transgressora e subversiva, mesmo em um contexto repressivo, em que prevalecem as relações de poder; ela tenta afirmar sua identidade de gênero e sexualidade.

A personagem, por várias vezes durante o espetáculo, narra sua felicidade por receber presentinhos e mimos dos outros presidiários, recorda com tristeza do preconceito verbal e físico que sofria em casa por parte do irmão. Tenta mascarar uma vida feliz dentro do presídio onde é elogiada, presenteada e amada por seus parceiros. Entretanto, para a atriz Liah Ramos (2014), Veronique quer mais que presentes:

Veronique quer ser amada como qualquer outro, por isso sua falsa concepção sobre isso é ecoada durante toda a fala dela. E há um discurso social bastante forte também, como a relação com policiais corruptos e o sistema prisional que a rodeia, e sim, a questão de identidade e gênero.

Assim, Veronique deseja ser amada, ter seus direitos e sua identidade de gênero reconhecidos. Almeja viver sua sexualidade e performatividade de gênero feminina sem retaliações e preconceitos. Porém, seu corpo queer incomoda a normatividade binária e, por isso, a sociedade lhe destina a fronteira, a clandestinidade e a ilegalidade porque "a dinâmica de sua identidade questiona padrões heteronormativos e desnaturaliza aquilo que, até então, se entende como modelo de família, de trabalho (vida profissional) e relações afetivas" (Ferreira, 2010, p.03).

Nesta perspectiva, o corpo queer de Veronique desestabiliza as fronteiras normativas de gênero e sexualidade que na cena assume uma potência cênica-discursiva. Em Veronique (2014) predomina na estrutura dramática a tradição teatral aristotélica, entretanto a poética queer estava presente na construção discursiva da dramaturgia, além da criação da caracterização do corpo queer da personagem e também da atriz, reverberando em discursos queer que narram os conflitos e anseios das travestis carcerárias. Sendo assim, é através do travestismo (Trevisan, 2002; Trostoy; Lima, 2006; Lozano, 2013) que Liah Ramos construiu um feminino que problematiza o corpo queer da travesti Veronique.

Portanto, em Veronique (2014) o palco fictício é apenas um refúgio para retratar a realidade de outro palco, o da vida real, dura e crua das travestis carcerárias, que cotidianamente reinam "[...] no mundo subversivo das drogas, reinam no submundo dos prostíbulos, assim como na alcova 'sagrada' do/a deputado/a, do médico/a do/a juiz/a, do/a gari ou do/a professor/a" (Sá-Silva, 2012, p. 5). E reinam ainda em outros espaços discursivos, nos quais adentram para ocuparem e se legitimarem frente ao processo histórico de marginalidade e invisibilidade.

Atualmente, reivindicam também a representatividade na cena das artes cênicas contemporâneas. Desse modo, estes corpos queer já vivenciam em suas práticas sociais no cotidiano, lugares de margens e de deslocamentos nos quais as identidades LGBTI's são obrigadas, pela sociedade normativa, a viverem (Delgado, 2013). 
$\mathrm{Na}$ historiografia do travestismo ludovicense os corpos queer adentram esta cena subvertendo as normas binarias de gênero (Butler, 2003; Louro, 2016; Delgado, 2013) ao reivindicarem no teatro não somente o lugar na comédia do gênero besteirol, ainda que este, historicamente, tenha sido o gênero dramático que oportunizou que personagens LGBTI's adentrassem a narrativa dramática, como no espetáculo Uma linda quase mulher (1999), por exemplo, sob o viés do estereótipo, da caricatura sátira. Protagonizar outras estéticas, gêneros dramáticos e performáticos potencializam seus próprios discursos em cena, dando voz aos seus conflitos, anseios e discussões em outras construções de poéticas queer de representação e representatividade.

\begin{tabular}{|c|c|c|c|}
\hline & $\begin{array}{l}\text { Estrutura dramática/ } \\
\text { Performativa }\end{array}$ & Caracterização & $\begin{array}{l}\text { Representação e } \\
\text { Representatividade trans }\end{array}$ \\
\hline $\begin{array}{l}\text { Auto do Bumba meu boi } \\
\text { (séculos XIX-XX e XXI). }\end{array}$ & $\begin{array}{l}\text { A estrutura dramática é baseada } \\
\text { em um enredo que discorre acer- } \\
\text { ca dos personagens Francisco, } \\
\text { Catirina e o boi Mimoso. (Borra- } \\
\text { lho, 20012), Não problematiza } \\
\text { as discussões de gênero. (Lima; } \\
\text { Albernaz, 2013). }\end{array}$ & $\begin{array}{l}\text { Neste folguedo, cuja origem re- } \\
\text { mete ao século XIX (Borralho, } \\
20012 \text { ), a personagem Catirina } \\
\text { é, tradicionalmente, interpretada } \\
\text { por homens cis. Na maioria das } \\
\text { representações de Catirina, os } \\
\text { brincantes constroem o estere- } \\
\text { ótipo da mulher negra de forma } \\
\text { caricata, com acentuada maquia- } \\
\text { gem, vestida com roupas colori- } \\
\text { das, além de gestos que objeti- } \\
\text { vam fazer a plateia rir. }\end{array}$ & $\begin{array}{l}\text { O travestismo em Catirina mostra } \\
\text { a representação da mulher cis } \\
\text { heterossexual, além de outras } \\
\text { demarcações identitárias de gê- } \\
\text { nero, raça, classe, dentre outros. } \\
\text { (Lima; Albernaz, 2013). Na atua- } \\
\text { lidade existem grupos de Bumba } \\
\text { meu Boi que apresentam Catiri- } \\
\text { nas representadas por homens, } \\
\text { assumidamente, como homos- } \\
\text { sexuais afeminados e também } \\
\text { mulheres cis. }\end{array}$ \\
\hline $\begin{array}{c}\text { Uma linda quase mulher } \\
\text { (1999) }\end{array}$ & $\begin{array}{l}\text { A dramaturgia aristolética apre- } \\
\text { senta o romance entre a perso- } \\
\text { nagem Júlia Roberta e Ricardo } \\
\text { Gerardo. O gênero dramático } \\
\text { besteirol expõe o coditianodas } \\
\text { travestis ludovicenses. } \\
\text { A dramaturgia é uma sátira do fil- } \\
\text { me hollywoodiano Uma linda mu- } \\
\text { Iher, sucesso na década de } 1990 \text {. }\end{array}$ & $\begin{array}{l}\text { Em Uma linda quase mulher } \\
\text { (1999) as personagens Cíntia } \\
\text { Sapequara, Júlia Roberta, Léa } \\
\text { BigBig de BH, Mia Cara de Gato } \\
\text { representam, de forma esterioti- } \\
\text { pada, travestis prostitutas de São } \\
\text { Luís - MA. A construção do femi- } \\
\text { nino através de preenchimento } \\
\text { com espumas para acentuar os } \\
\text { seios e bumbuns, além de pe- } \\
\text { rucas extravagantes, de acordo } \\
\text { com os atores, foram inspiradas } \\
\text { nas travestis do coditiano local, } \\
\text { assim como em mulheres cis que } \\
\text { permeavam o imaginário popular } \\
\text { na década de 1990, represen- } \\
\text { tadas na TV, a saber: Tiazinha, } \\
\text { Feiticeira e Bethy Boop. }\end{array}$ & $\begin{array}{l}\text { No espetáculo a representação } \\
\text { do travestimo é apresentada por } \\
\text { atores cis (homossexuais e he- } \\
\text { terossexuais) interpretando per- } \\
\text { sonagens trans. As discussões } \\
\text { acerca da visibilidade trans aden- } \\
\text { tram à cena ludovicense, ainda } \\
\text { que timidamente, na década de } \\
1990 \text {. }\end{array}$ \\
\hline $\begin{array}{l}\text { Travesqueens } \\
\text { (2011) }\end{array}$ & $\begin{array}{l}\text { A estrutura performativa do es- } \\
\text { petáculo traz elementos da cena } \\
\text { performatividade, na qual proble- } \\
\text { matiza representações de corpos } \\
\text { trans marginalizados nos estados } \\
\text { de Maranhão, Paraná e Piauí. A } \\
\text { montagem está inserida no con- } \\
\text { texto de uma poética queer que } \\
\text { aborda a situação das travestis } \\
\text { em diversos estados brasileiros, } \\
\text { numa montagem com elementos } \\
\text { da dança contemporânea, per- } \\
\text { formance e teatro performativo } \\
\text { (Féral, 2009). }\end{array}$ & $\begin{array}{l}\text { Neste espetáculo os artistas cis } \\
\text { Erivelto Viana como Cíntia Sa- } \\
\text { pequara, Elielson Pacheco como } \\
\text { Soraya e Ricardo Marinelli como } \\
\text { Princesa Ricardo constroem uma } \\
\text { pluralidade de corpos trans, com } \\
\text { caracterizações que acentuam } \\
\text { esteriotipos do feminino até des- } \\
\text { contruções que performatizam } \\
\text { corporeidades híbridas. }\end{array}$ & $\begin{array}{l}\text { Na montagem verificamos como } \\
\text { as poéticas queer são constru- } \\
\text { ídas a fim de discutir a respeito } \\
\text { dos corpos trans em contextos de } \\
\text { marginalidade na sociedade atu- } \\
\text { al. As discussões de visibilidade } \\
\text { trans são apresentadas a partir } \\
\text { de três artistas cis (homossexu- } \\
\text { ais) que performatizam feminili- } \\
\text { dades e materializam os corpos } \\
\text { de mulheres transexuais. }\end{array}$ \\
\hline
\end{tabular}




\begin{tabular}{|c|c|c|c|}
\hline $\begin{array}{c}\text { Veronique } \\
\text { (2014) }\end{array}$ & $\begin{array}{l}\text { Apresenta uma dramaturgia com } \\
\text { estrutura prioritariamente aristo- } \\
\text { télica, para narrar a história de } \\
\text { opressão da travesti Veronique } \\
\text { no sistema prisional do Carandi- } \\
\text { ru. Discute a respeito da situação } \\
\text { marginalizada das travestis car- } \\
\text { cerárias. }\end{array}$ & $\begin{array}{l}\text { Por meio do travestismo (Trevi- } \\
\text { san, 2002; Trostoy; Lima, 2006) } \\
\text { a atriz transexual Liah Ramos } \\
\text { construiu um feminino que pro- } \\
\text { blematiza o corpo queer da tra- } \\
\text { vesti Veronique. Através de uma } \\
\text { caracterização que evidencia o } \\
\text { suplício no qual os corpos trans } \\
\text { sofrem em contextos carcerários. }\end{array}$ & $\begin{array}{l}\text { No espetáculo a personagem Ve- } \\
\text { ronique, compartilha narrativas } \\
\text { trans de uma travesti carcerária, } \\
\text { materializada pela atriz transexu- } \\
\text { al Liah Ramos. Com Veronique } \\
\text { as póeticasqueer na cena de } \\
\text { travestismo constroem represen- } \\
\text { tividades ao colocar nos palcos } \\
\text { o corpo da atriz transexual que } \\
\text { expõe narrativas trans. }\end{array}$ \\
\hline
\end{tabular}

Tabela 1: Síntese das considerações acerca das Poéticas Queer $\mathrm{Na}$ cena de travestismo em São Luís (MA)a de travestismo em São Luís (MA) Fonte: elaborada pelos/as autores/as.

Este quadro ilustra o panorama do travestismo em São Luís (MA), demonstrando o recorte dado o qual evidencia uma cena em transição, com montagens que apresentam o travestismo enquanto representação de mulheres cis, assim como associado às poéticas queer de visibilidade das discussões de pessoas trans com seus anseios e questões político-sociais. Além de espetáculos, a exemplo de Veronique (2014), o qual apresenta poéticas queer de representatividade das discussões acerca das mulheres trans na cena contemporânea ludovicense.

\section{Considerações Queer}

Em linhas gerais, apresentamos recortes de uma cena de travestismo ludovicense, na qual o recurso do travestismo foi utilizado como técnica para representar personagens femininas cis e trans, principalmente enfatizar o protagonismo de travestis e transexuais no teatro local em diferentes estéticas teatrais e performativas.

Nesta historiografia do travestismo no teatro ludovicense, inicialmente exemplificamos a partir do Auto do bumba meu boi, ainda no início do século XIX, como as mulheres eram segregadas dos palcos maranhenses, sendo a personagem Catirina interpretada por brincantes, o que revelou como as relações de poder e preconceito influenciavam o metié deste folguedo.

Posteriormente, o espetáculo Uma linda quase mulher (1999), no final do século passado, colocou nos palcos de São Luís mulheres trans, transgredindo os padrões heteronormativos que até então desenhavam a cena teatral de São Luís (MA). Ainda que esta montagem evidenciasse a construção de um feminino cômico, em diálogo com a proposta do gênero dramático besteirol, tornou-se um grande marco para o panorama do travestismo no qual personagens trans foram protagonistas.

Não obstante, nas montagens Travesqueens (2011) e Veronique (2014), identificamos discussões a respeito das mulheres trans, construindo poéticas queer que se refletem em implicações subjetivas e discursos político-sociais através de representações e representatividades trans. Os corpos apresentados nestes espetáculos eram deslocados e subversivos, porque desestabilizavam as normas binárias, que até então protagonizavam o teatro ludovicense. Corpos queer que ecoaram outras vozes de sujeitos que não tinham visibilidade e representatividade no panorama teatral local e que reivindicavam falarem de si, serem protagonistas dos seus próprios discursos, cujas identidades pertencem aos/as personagens LGBTI's. 
Isto posto, enfatizamos que nesta pesquisa almejamos contribuir para a história do travestismo no teatro brasileiro associado ao protagonismo de mulheres trans, em diálogo com os estudos queer, haja vista que em nossas hipóteses iniciais, existia uma lacuna na historiografia teatral de São Luís no que diz respeito à prática artística de construir personagens femininas transexuais. Além do mais, a visibilidade e representatividade, a que tanto nos referimos também perpassapelo interesse de investigar, discorrer e apresentar a história e o percurso artístico que envolvem mulheres trans e demais LGBTI's.

Portanto, ressalta-se a importância de descortinar a história do teatro e revelar os espetáculos nos quais homens interpretaram personagens femininas, a fim de problematizar os discursos de gênero e as relações de poder que influenciaram nessas representações das mulheres nos palcos de São Luís (MA). Reconhecemos que a inserção da história da prática teatral realizada na região Nordeste ainda carece de difusão, principalmente levando em consideração as particularidades de fomento cultural e estéticas pertinentes a regionalidade.

Por fim, o ensaio apresentado pretende contribuir para uma descentralização sobre os estudos de gênero no âmbito do teatro brasileiro. Assim, a investigação destaca-se pelo pioneirismo em discutir a representatividade das mulheres trans na cena teatral maranhense, que contribui para fomentar o cenário cultural do Maranhão e a cena teatral nacional.

\section{Referências}

ARAÚJO, Mateus Araújo. Questões sobre a representatividade trans no teatro. Disponível em:<https://www.revistacontinente.com.br/secoes/artigo/questoes-sobre-a-representatividade-trans-no-teatro>. Acesso em: 30 jun. 2018.

AMORIM, - Paloma Franca. 'Gisberta', de Luis Lobianco: representacao e representatividade nas artes. Disponível em: <https://painelacademico.uol.com.br/ espaco-alameda/9958-gisberta-de-luis-lobianco-representacao-e-representatividade-nas-artes>. Acesso em: 30 jun. 2018.

BUTLER, Judith. Problemas de gênero: feminismo e subversão da identidade. Tradução, Renato Aguiar. Rio de Janeiro: Civilização Brasileira, 2003.

BORRALHO, Tácito Freire. O teatro do boi do Maranhão- brincadeira, ritual, enredos, gestos e movimentos. São Paulo: USP/Escola de Comunicação e Artes. 2012.

CASSEMIRO, Luiza Carla. Tenho o direito de ser "Amapô": as trajetórias de travestis e transexuais face a implementação das políticas públicas de assistência social e saúde. Rio de Janeiro. 2010.

CONNEL, Raewyn, PEARSE, Rebecca. Gênero uma perspectiva global: compreendendo o gênero - da esfera pessoal à política - no mundo contemporâneo. Tradução e revisão técnica Maria Moschkovich. 2015. Editora: Nversos. 
DELGADO, Pedro Omar Lacerda. A Queerização do corpo no Teatro de João Carlos Castanha. 2013, 215 p. (Mestrado) - Programa de Pós-Graduação em Artes Cênicas, Universidade Federal do Rio Grande do Sul, Porto Alegre, 2013. Disponível em: http:// www.lume.ufrgs.br/bitstream/handle/10183/78758/000900581. pdf? sequence=1. Acesso em: 11. jun. 2017.

DOURADO, Rodrigo Carvalho Marques. Bonecas falando para o mundo: identidades sexuais "desviantes" e teatro contemporâneo. Tese de Doutorado, 2014. 237 f.

FÉRAL, Josette. Por uma poética da performatividade: o teatro performativo. Sala Preta, USP, v. 8, 2008. Disponível em:<http://www.revistas.usp.br/salapreta/article/ view/57370>. Acesso em: 11. jul. 2017.

FERREIRA, Valmir Aleixo. O teatro homoafetivo na contemporaneidade: estudos sobre torchsongtrilogy. Fazendo Gênero 9. Diásporas, Diversidades, Deslocamentos. 23 a 26 de agosto de 2010.

FOUCAULT, Michel. Vigiar e punir: nascimento da prisão. Tradução: Raquel Ramalhete. Petrópolis, Vozes, 1987.

JANSEN, José. Teatro no Maranhão: até o fim do século XIX. Rio de Janeiro, 1974.

LEITE, Aldo de Jesus Muniz. Memória do teatro maranhense. São Luís. Ed. FUNC, 2007.

LOURO, Guacira Lopes. Um corpo estranho: Ensaios sobre sexualidade e teoria Queer. Belo Horizonte. Editora: Autêntica. 2016.

LOURO, Guacira Lopes. Gênero, sexualidade e educação: uma perspectiva pós-estruturalista. 9. ed. Petrópoles, Ed. Vozes, 1997.

LINS, Beatriz Accioly. Diferentes, mas não desiguais: a questão de gênero na escola. 1a ed. São Paulo: Editora Reviravolta, 2016.

LOZANO, Ezequiel. Performatividad de Género y Travestismo através de Escenificaciones de Las Criadas de Genet. Revista Brasileira de Estudos da Presença, Porto Alegre, v. 3, n. 3, p. 805-818, set./dez. 2013. Disponível em: <http>://www.seer.ufrgs. $\mathrm{br} /$ presença>. Acesso em: 10 set. 2018.

LIMA, Patrícia Geórgia Barreto de; ALBENAZ, Lady Selma Ferreira.Gênero e Cultura Popular: relações de poder, posições e significados da participação das mulheres nos grupos de Bumba - meu - Boi do Maranhão. $R S+h$, v. 26, n. 3, p. 489 - 508, set/dez 2013. Disponível em: <https://periodicos.ufsm.br/sociaisehumanas/article/ view/2836/pdf>. Acesso em: 10 jul. 2017. 
LOSADA, Valência. A insurgência trans e seu alvo impreciso. Disponível em: <https:// revistacult.uol.com.br/home/gisberta-luis-lobianco-ccbb-bh/>. Acesso em: 30 jun.2018.

Movimento Nacional de Artistas Trans - MONART. Representatividade trans. Disponível em: <https://web.facebook.com/RepresentatividadeTrans/phot os/a.1873789022890665.1073741828.1847876488815252/1996303500639216/?type=3>. Acesso em: 15 mai. 2018.

Transfake em Gisberta - Movimento Nacional de Artistas Trans. Disponível em: <https://www.youtube.com/channel/UC_XYB1etYxKSIOwkl7oLMCA/ videos>. Acesso em: 15 mai.2018.

PEREIRA JUNIOR, Jurandir Eduardo. Nem homem, nem mulher, gente: trajetória do grupo Dzi Croquettes entre o passado e reflexões no presente. 2016, 210 p. Dissertação (Mestrado em Teatro) - Programa de Pós-Graduação em Teatro, Universidade do Estado de Santa Catarina, Florianópolis,2016.

PEREIRA, Abimaelson Santos. Transgressões Estéticas e Pedagogia do Teatro: o Maranhão no século XX. São Luís, EDUFMA, 2013.

REIS, Luís Augusto. 1974. Cinderela: A história de um sucesso teatral dos anos 90. Recife: COMUNIGRAF, 2002.

ROSENFELD, Anatol. A arte do teatro. Publifolha: São Paulo, 2009.

SÁ-SILVA, Jackson Ronie. As bonecas e seu reino. São Luís, 2012.

SALIN, Sara. Judith Butler e a teoria Queer. 1ํed. Belo Horizonte. Autentica Editora. 2015.

TEIXEIRA, Ubiratan. Bastidores: crônicas de teatro. São Luís. Ed. Secma, 2012.

TRASTOY, Beatriz; LIMA, Perla Zayas de. Travestirse en escena: el hábito que hace al monje. Revista Telondefondo - revista de teoría y crítica teatral. Año II. Julio 2006.

TREVISAN, Jorge Silvérío. Devassos no paraíso: (a homossexualidade no Brasil, da colónia à atualidade)/de Jogo Silvério Trevisan. Ed. revisada e ampliada -- 5' ed. -- Rio de Janeiro: Record, 2002.

THERCIANE, S. S.; RAMOS, C. de M. de A. Designações para o sujeito "homossexual masculino", em São Luís: um estudo de natureza lexical. In: CONGRESSO INTERNACIONAL DE DIALETOLOGIA E SOCIOLINGUÍSTICA, 2012, São Luís - MA. Anais... São Luís - MA: UFMA, 2012. p. 2644-2652. 